\title{
Studying the Identity of Iranian Classical Effective Literature and Contemporary Impressible Literature
}

\author{
Abdolmajid Mohaqeqi \\ Yasouj University, Iran \\ E-mail: mohagheghiabdolmajid@yahoo.com \\ Peyman Faramarzi \\ Jamileh Mohaqeqi
}

Received: 03-06-2014

doi:10.7575/aiac.ijalel.v.3n.6p.145
Accepted: 19-07-2014

Published: 01-11-2014

URL: http://dx.doi.org/10.7575/aiac.ijalel.v.3n.6p.145

\begin{abstract}
After the advent of Islam in Iran, Persian Literature has always been considered as one of the major characteristics of Iranian culture and identity to the extent that some people believe whatever western has achieved in terms of literature especially English literature - and honors to them originate from rich Persian literature. However, Persian literature has severely been influenced by works of western writers in contemporary era so that even modern Persian story and poem is divided based on western styles. Unfortunately, this situation - that a part of identity of Iranian culture has been drastically affected by alien culture - offends each educated Iranian. Today, a flashback to Iranian classical styles does not meet the need for a development created in literary works. However, it is necessary that tasteful and patriotic people create novel works in Iran's contemporary literature against the decades-old literary identity of the west through adaptation of past-targeted literature and under the effect of conditions of today modern society in order to recover the lost identity of Iranian literature which other fields are considered as its subset. Therefore, this paper is going to present solutions for modeling the identity of Iranian literature for the next two decades in line with Islamization of universities in order to divide the pure academic literature into pure and applied sub-branches and develop academic literary activities. As a result, the international works would be established based on the columns of Persian literature whose kernel will not to be damaged in the rain and wind of alien cultures.
\end{abstract}

Keywords: Islamic Iranian identity, western philosophy, Persian literature, contemporary literature, art

\section{Introduction}

Certainly, culture and cultural relics are among the most obvious manifestations of identifying each nation in the current disordered world that reveal as one of the indices of language, country, ethnicity, etc. and are introduced to other nations. Literature as one of the greatest cultural characteristics of each nation or as one of the interdependent cultural reasons can be significantly affective in introducing culture as a whole set of façade of understanding a nation.

Iranian literature has always been dynamic during the vicissitudeness history of this country and appropriately able to find its place in the world of classic literature and introduce Iran and Iranians to the world. Whether at the time when Iran meant Iranian plateau, when it was identified as the whole concept of the east in the mind and language of the world, or during the flourishing of Islamic civilization that Islamic Iran boasted and its literature succeeded to combine its properties with principles of Islamic culture and define novel basis for poetry and literature in the world with the help of Arabic and its literature.

According to a large number of culturists, a collection of Iranian culture has been formed in the word by which Iran has always been identified in spite of many political and geographical changes and great ethnic, linguistic and national expansion. In the meantime, literature, especially poetry, can be accounted as one of the most prominent elements or properties of the Iranian culture that has been more effective than other elements in forming the collection of Iranian culture in the world and even can be considered as the symbol of this culture (Salasi, 2012, p 23).

Iranian literature succeeded to establish a position for itself in the world due to various reasons including the existence of metaphysical, humanitarian, historical, and cultural principles. As a result, Goethe was fascinated by Hafiz and Saadi's poem was stamped over the door of UN due to the presence of altruism principles in order to be a lesson to the world of Iranian philanthropist and human-centered culture having been established based on the lofty divine and Islamic foundations.

Various styles in Iranian literature indicate its dynamism towards sublimity so that the further way we come from the early period of Persian poetry, the more complexity we find in language and thought of Persian poetry and prose which is indicative of sublimity development in the Persian literature. With the arrival of mysticism and religious and 
philosophical ideas in to the realm of Persian literary thought and technical writing in to the Persian language, Persian literature met such a position that no one was able to analyze it.

Unfortunately, this dynamic literature has fallen in stillness and passivity in a period called Return and imitation bands were hung around its neck to muffle it. However, some people again hasten to help Persian literature in order to save it through imitation of the west, so that the possibility of imitation had been started by the development of relations between Iran and the west. It was when unprecedented extremes and wastages in novel styles were to take the identity of Iranian literature for the first time and transform it to a mimic literature from alien cultures. Although, extremely using literary arrays and fantasy in Indian and Isfahani styles, extremely imitating the past and putting too much emphasis on approaching the style of classical elders in Persian poetry and literature during the period of return caused the conditions for the early decline of poem. Persian prose which had become a unique prose in Islam world due to its brilliant background in rhythmic, technical, and simple writing, etc. got involved in imitation of western styles sooner than poetry, so that rapidly spent periods of nihilisms.

On the other hand, establishment of university in Iran and the change of Persian language and literature as an academic field was not so affective in saving Persian literature from the trap of imitation of the west because of the overemphasis of this field on the recognition of classical style and its lack of adaptation to up-to-date literary needs of the society. Although today's Iranian poetry and literature is distinctive from literature of other nations due to its special characteristics and its recognition needs to the formation of critique and criticism styles which have originated from its heart, unfortunately all the published literary criticism books based on which Persian literature is criticized include western and foreigner criticism styles. This is considered as Iranian literature's weakness and Persian language and literature has not yet been able to find an appropriate solution in the context.

\section{Iranian Literature in the World}

Iranian culture was so strong that could easily influence each invader after any attack to the country. In fact, whenever Iran lost against any invader in terms of military force, it fought with invaders using culture, trained the uncultured invader in its own right way, and enamored him with its rich culture. The extensiveness of Iran in ancient times and being the first power of ancient world had provided such a place for the name of Iran anywhere in the world, so that even the philosophical Greek included signs of Iran and Iranian in itself at that time. The author of "Iran and its Loneliness" refers to the power of Iranian culture and says, "The recognition of Iran in the west owes to the wars which Achaemenids fought with the Greek (Eslami Nedushan, 1997, p 114). The geographical extension of Iran and traveling of different nations to Iran from Greeks and Arabs to Mongols and Turks of Asia Minor led to the spread and show-off of the Iranian culture broadly and geographically.

Many nations of the world presented or imposed their own culture on other lands by invading them. However, history shows that invaders who attacked our country, such as Mongols and Greeks, they themselves were influenced by Iranian culture.

Iranian culture was known before Islam by Europeans. After Islam, it widely influenced the east as well, so that it had such a position and influence on its neighbor country - India - that was considered as one of the greatest bases of Persian poem and literature during Safavid period up to a long time, and created a new famous literary style called Indian. Jawaharlal Nehruin the book" Discovery of India" wrote, "Among different nations and races having been in touch with Indian life and culture and penetrated in it, Iranians were the oldest and the most consistent. This relation is even older than the onset of Aryan and Indian civilizations because Indians, Aryans, and old Iranians had a common root but had been separated later. Their race is related to each other, old Indian religion has some common aspects with Zoroastrian religion and the Sanskrit; and Old Pahlavi language is similar to Avestan language"(Jawaharlal Nehru, 1983, p 125).

Iranian culture had such a power and capacity that was not afraid of trading with any other cultures, always welcomed other cultures happily and with open arms, and took advantage of cooperating with them without showing any capitulation. This fixed and productive effect has not yet been lost in current Iranian culture and it may be possible to take control of world's cultural market in the case of favorable contexts and suitable grounds is provided (Salasi, Ibid, p109).

Will Durant has also referred to the influence of Sassanian art and culture on the east and west in his book" The History of Civilization" and says, "Sassanian art paid its debt through spreading its own artistic forms and motives on the east (India, Turkestan, and China) and west (Syria, Asia Minor, Constantinople, Balkans, Egypt, and Spain). Its penetration into the Greek art caused Greek to leave its persistence on playing classical images and incline to the decorating approach. It also helped Latin Christian art in paying attention to transform of wooden ceilings to dome, made of brick or stone and stack walls. The art of building large gates and domes dedicated to Sassanian architecture was transferred to Islamic masques and Mongols' palaces and temples. Nothing will be lost in history. Any creative thought will achieve development opportunity sooner or later and adds its own color and flares to life" (W. Durant, 2000, p 185).

Since five to six thousand years ago, Iran's Plateau has continuously been one of the culture maker and welcoming areas. Iranian ethnic groups both created and spread cultural elements in the world (Salasi,Ibid, p 135).

Persian literature having always been one of the greatest cultural components of the nation succeeded to develop along with other cultural works in the world due to this dynamism of Iranian culture and show off as one of the best cultural works. On the other hand, due to extensiveness of Iran's geographical and cultural domains, there has always been 
Persian poets and authors in different parts of the land that despite of having principle differences in terms of race and subcultures were able to create close styles.

Poets having style in Persian poetry were dispersed in a wide area of the world from Transoxiana to Asia Minor and India and composed poem in Persian language. At that time, even the farthest places of the world such as China have not been out of influence of Persian poetry (Ibid,24). It caused different manifestations of cultures spread in a literature with common language and coordinated grammatical and linguistic structures were apparent and they quickly became popular because of their harmony with literary needs of different societies. This effective and prominent literature was actually the common word of people who spoke Persian or lived within the geographical area of this language. Therefore, it shows that the influence of Persian literature in the early centuries of its formation was due to the importance of current ideas in it, so that it still stands stable despite the change of Pahlavi alphabets to Arabic. According to Dr. Abdol Hossein Zarrinkub, although two centuries of silence prevailed Persian literature, it quickly wears new clothes by accepting new appearance which was the Arabic alphabet and states its ideas behind this new language. Persian literature takes formats, prosodic Meters, and syllabic poem from Arabs and dynamically reflects Iranian thought and civilization with them. Imitation of Meter from Arabic not only does not stop its activity but also opens a new way in front of Persian language. People began to innovate, create, and promote whatever Arabs were not be able to test in these Meters. Therefore, Persian literature creates Sonnet, Multiple Poem and Quatrain formats for the first time or considers a new definition for them.

Persian poetry had a better position than prose after Islam because of courtiers and kings' attention to it, encouraging poets, and granting gold to them.

"Poetry enjoys a lofty position in Persian literature. The first samples of poems obtained in Irandates to the Prophet Zoroaster's day and his poems in the courts. These poems are dialects of Avestan language" (Wikipedia).

Although the early Persian poems in the third and fourth centuries A.D. did not have the same features and ambiguities of poems in next centuries, they were the base for Persian poetry to be recognized as one of the best literary types of that time in all over Iran and even in Islamic lands. Certainly, by the advent of Ferdowsi's Shahnameh in Persian literary world, epic emerged in its true and serious meaning, along with or even ahead of epic of the world, as a prominent tool for introduction of Iranian myths. Epic also provided a lofty position for Persian poetry, so that a style was later created for criticizing Persian poetry and following the widespread advent of court poets, creation of poet laureate ranks, etc. because any work cannot be proposed and effective as poem and literary work. It should be known that, "Persian classic poetry includes global characteristics and shows a universal state with abstraction of a specific area or ethnic group" (Salasi, ibid, p 25).

Coordinated activities and common literary frequencies among classical Persian-language poets and authors of this vast land lead to recognition of literary styles having been formed in the land that mostly are introduced according to the name of the region in which most poets wit that style properties were presence. Multiplicity is one of the most important indices of Persian language and literature and particularly shows that stagnation has not only not been characteristic of Persian literature but has also been the mobility of its prominent index, so that broad location multiplicity is one of the millstones of this literature.

Indices based on which the effect of external factors on style is evaluated generally with their subsets include environment and people, culture and livelihood.

Environment (including natural geography, and social/political developments), people (including family, general public), culture (including language/ dialect, customs, habits and beliefs; intellectual/literary/ artistic parties, ethnic/historical background), and economy (job and profession/social class, and livelihood conditions of people)(Shiri, 2004, p 151).

Dr. Sirus Shamisa divides Persian poetry into 8 periods as well. According to this division, the main styles include Khorasani, Iraqi, and Indian.

1. Khorasani style: the second half of the third century, fourth and fifth centuries;

2. Intermediate style or Saljuk Period style: sixth century;

3. Iraqi style: seventh, eighths and ninth centuries;

4. Intermediate style or occurrence and far burning school: tenth century;

5. Indian style: eleventh century and the first half of twelfth century;

6. Return period: mid-twelfth century to the end of thirteenth century;

7. Intermediate style or constitutionalism period: the first half of fourteenth century;

8. New style: the second half of fourteenth century onwards"(Shamisa,1999, p13-14).

However, the story of Persian literature's movement towards a new style in contemporary era not only is not indicative of effectiveness and growing of this literature but also is transformed into a tragedy of imitation. So that with the advent of new styles called western scientific literary writing, the shade and domination of western literature can be seen in new styles and it increases every day.

\section{Combination of Mysticism and Poetry and Their Introduction by Each Other}

Islamic Mysticism and Sufism originated from Islam's heart succeeded to take widespread properties among Muslims. With the emergence of conflicts between believers and mystics, mysticism was proposed as one of the most controversial subjects that its basis as theoretical mysticism was separated from practical mysticism. Transforming 
Persian literature, especially poetry, to mystic language and using symbolism, two other properties were considered for Persian poetry. First, it was saved from the trap of descriptions and flatteries, proposed newer topics, and a new method was established in Persian poetry using symbolism. Second, its audiences increased and developed from among minority of courtiers to general and specific segments of society that undoubtedly contributed to development of poetry more than before and poetry was transformed to the tool of mystic poets' expression.

Islamic Mysticism is one of the valuable achievements of Islamic civilization that has grown and developed during different periods and has influenced the results of great Islamic mystics' passionate thoughts in human civilization. Magnificent manifestation of this effect can be seen along with social and intellectual developments in Islamic arts, so that area of literature more than other fields has been a good opportunity for expressing such ideas (Akhgari, 2011, p 2).

Sufi poetry is full of symbols and secrets about which commentaries were written but none has been able to offer the spirit of that spiritual experience to the audience. Sufi poetry is the best area for literary parade. In Sufi poetry, one can combine his/her own experiences with a symbolism which is dedicated to a Sufi. Furthermore, in Sufi poetry one deals with love and the beloved and sometimes this experience becomes so ambiguous that realizing whether the love is true or virtual is difficult. Dr. Zabihallah Safa believes that penetration of mysticism and Sufism in poetry began from the sixth century. In" The History of Persian Prose and Poetry Evolution", he says, "The entry of mystical problems in poetry first, led to creation of a specific variety in Persian poetry which was given a new color. Second, it changed dedication of poets to courts to some extent, so that poets appeared who created literary masterpieces outside Sultans' courts" (Safa, 1985, pp 58 \&59). Sufi poetry has always emphasized the presence of God. However, Sufi prose has tended to systematically explain beliefs and acts (Chitic, 2004, p65).

Features such as being God-centered, symbolism, ambiguities of speech, lack of attention to human's physical aspect, etc. have granted such a state to Persian mystical poetry that they are the base of thought direction of composing mystical poetry in the world. For centuries before the establishment of symbolism by western symbolists, Persianlanguage Sufi poets considered such symbols for their language and stated that most of their aspects still need a more complete analysis and worldwide despite years of Orientalists and many local commentators' effort. It can certainly be said, "Persian mystical poetry is indicative of the most subtle, humanely, and global aspect of Iran's cultural territory" (Salasi, Ibid, p25).

Mysticism itself being reached to higher levels of its sublimation and somehow took Iranian color after creation by Iranian mystics, is also one of the dynamic and floating factors Iranian culture that introduced our literature to all over the world at that time due to introducing itself. "In fact, Islamic Sufism and mysticism is one of the other factors of Iranians' mobility in the wide and civilized Iranian- Islamic world...Iranian Sufis and mystics were not dependent upon any place and believed that one of the ways of mystical conduct is the practical journey from one point to another point. This feature had floated their intellectual and taste school too much and caused that no city and area was empty of monasteries and angles of Iranian mystics and Sufis in Middle Ages of Iranian-Islamic civilization" (Ibid, p 75).

Iranian mystics have been able to live in any pale in the world and promote Iranian thought and spirit as it is quoted, "One of the disciples of Sheykh Safiyadin Ardabili, Mohammad Ali Shah, born in Hamedan went to Deccan in India and took the highest position in the court of king. He finally became the official ruler of Deccan and founded the dynasty of Qutb Shahi in 918 A.D." (Ibid, p80). Rabia Adviyeh, the great mystic woman of the eighth century, was the first figure of Islamic mysticism that was proposed in European literature. June Will, the prime minister of Louis IX in the late thirteenth century, brought her legend to Europe (Akhgari, 1389, p 34).

Hafiz, Molavi, Saadi and many other mystical-minded thinkers in Iran became famous in the world due to their works being full of symbolism and mysticism that undoubtedly paid attention to anthropology and today's world along with future. Today, these figures not only in the east but also in the west have their own special position and this global ranking is undoubtedly due to two factors including, first, their literary and excellent works, second, their lofty and spiritual thinking that is beyond the physical world and has blown spirit into poetry and their works. One of the Western samples influenced by Islamic mysticism is "Dante's influence by Islam and Islamic mysticism to which most pundits have referred" (Akhgari, Ibid, p 34).

Not in vain, even in western material-thinking and instrumental world, Rumi's works being a type of explosion in aesthetics are among bestselling books of the day. We cannot find any other author, poet or thinker who has written a book or another work at a corner of the east about eight centuries age that is popular in today's west which has less connection with Rumi'S time and place (Salasi, Ibid, pp 25\&26).

No other poet has been welcomed in west as much as Iranian and their books have not been translated to various languages as much as Iranians' (Ibid, p26). This is a great honor dedicated to Persian literature and our classic literature still has its own readers outside the boarders after centuries of writing the literary works and is welcomed everywhere.

Zigrid Hunke in "Islamic Culture in Europe" book says, "The effect of Islamic culture has mostly manifested in the west through literature, meanwhile Islamic mysticism has entered Western literature through Islamic literature"(Akhgari, Ibid, p 35).

However, the influence of Islamic Mysticism and literature on the west by tourists and Orientalists is more obvious, so that one of the sources through which western thinkers became familiar with Islamic mysticism is European tourists' logbooks (Ibid, p 36).

\section{Blackout the Bright Light of Contemporary Persian Literature}


After conquest of Iran by Arabs, Iranian always involved in governmental affairs of Islamic world, succeeded to cope with court jobs of administration and organize them, and fostered writers who taught the principles of writing to centuries onwards. At the time of Umayyad Caliphate, cooperation of Iranian teachers, administrators and agents was higher than before because the family of Umayyad, who had severe cultural and emotional dependencies and in that regard were similar to the Bedouins, just proud of sword and eloquence, hated court affairs, writing and treasury; and believed these works were not worthy for dignity and integrity of Arabs (Salasi, Ibid, p92).

Iranian activities in preparing the principles of writing and poesy, and criticism of Persian poetry and literature continued by writing books on the principles of rhetoric, poetry seas, semantics, etc. to the extent that it is possible to criticize most of classical works without the need for a new western writing principle and just by using those Iranian works.

Undoubtedly, Iranian culture always had cultural exchanges with other cultures and never encountered with them, so that books of Persian rhetoric principles include influences of Arabic.

On the other hand, there were no special boundaries for Iranian art before the Industrial Revolution like Iranian poetry and Mysticism. Iranian art continuously increased its domain and depth through artistic exchanges around the world. In the form of messages and abstract and taste patterns, it always enriched both itself and other cultures with which it was in exchange (Ibid, p29).

Iranian cultural integration and extent of communications within it had caused this culture and all its components, such as literature act strongly and in harmony with other centers, so that it is always possible to introduce it as a cultural empire in the word.

For the first time in history, an empire with absolute Iranian identity and features that had arisen from Iranian cultural context was divided between to lineages with Turkish race but Iranian (Ottoman and Safavid). If this empire had unity and did not suffer from schism, the world would have witnessed the last and most powerful empire and both parts of this unit body did not fall in weakness, deterioration, and backwardness (Ibid, p106).

But then, Iranian culture was very moving and floating until the eighteenth century and saw the easternmost and westernmost parts of the civilized world as its range of cultural creations. Iranian cultural society was very open, extroverted and worldwide due to this severe social and geographical mobility (Ibid, p107).

This extent and relationship with Europe soon appeared in some aspects of Iranian culture. Due to the advent of academic education and expansion of scientific relationships between Iran and newly civilized Europe, most Iranian youth inevitably educated abroad and severely influenced by foreign cultures. On the other hand, development of printing industry and journalism resulted in widely publishing of western works. If sometime western writing was considered a literary industry in Iran, at this time, the tendency towards Latin, French, Russian, and German languages was for boasting which not only did not helped the promotion of Persian language and literature but also led to imitations that later hurt the structure of Persian literature.

At this time, writers often had a special tendency to innovation and most of them went wrong, following imitation instead of innovation, completely closing their eyes on strong principles on which Persian literature was established, and were known as writers of cities like before, and were reminisced as authors of Tehran, Isfahan, Central, etc.."A small number of geographical aspects in Isfahani style is the result of over-climate attitude of the authors in this region. They have transformed challenging with national famous writers and indirect modeling from abroad authors as their own conventional and free manner" (Shiri, 2006, p169).

As mentioned, France, Russia, and Germany were the first literary entities that were considered by our new authors. "The history of literary relations between Iran and Russia is over a hundred years ago. These relations have led to more cultural and literary richness of both countries. Therefore, Iranian and Russian readers have found the possibility to become familiar with outstanding works of the two countries. If we, Iranians, today read the works of prominent Russian writers such as Pushkin, Turgenf, Dostoyevsky, Tolstoy and Chekhovin Farsi, Russian authors and readers have been familiar with Persian language masterpieces in their language since long before even about a hundred years ahead of us (Karimi Motahar, 2002, p 148).

The influence of western literature on Iranian scholars in many aspects returns to black aspects of European literature. The impact of their promising literature was not to the extent of the impact of western black literature on our authors and poets. This impact was so extensive that many Iranian poets and authors were recognized as authors of black poems and texts in the last period (period of widespread relation and influence of the West on Iranian literature), so that committing suicide, nihilism, or some baseless western humanism can be seen in the works of many Iranian authors.

In terms of subjects' evaluation, sensitivity to loss of human identity due to getting contaminated to anti-reason superstitions, uncontrollable sensual desires; sleep, passivity and crapulence; attachment to exciting and delightful desires, and loss of human free are major concepts in Worldview of authors in this region(Isfahan)(Shiri, Ibid, p175).

This influence developed in such a way that almost no other Persian intellectual foundations left behind and some types of prose were created in poetry that lacked any emotional foundations of Persian poetry. These types were called poems just because they were different from prose and were read in literary parties with honor, so that even readers and listeners who did not believe them, inevitably praised these works just for "When in Rome do as the Romans do". Unfortunately, although glimmers of hope were sparked in poetry after Islamic Revolution, the process of composing poems was not in accordance with enthusiasts of Persian poetry. 
Persian story writing changed with the arrival of western works to Persian prose and establishment of novel, short story, too short stories, etc. and the identity of Persian prose in terms of story writing changed into western approach. Although Iranian civilization history shows that Iranians were more active than westerns in this field and had unique stories at that time, they were westerns who again injected principles of story and novel writing to society. Stories such as Sadeq Hedayat's are the result of this wrong influence. Other new types of prose recently formed were completely imported such as journalism.

In the area of styles, frequencies by which styles were distinctive in literature were renamed in western terms and excellent styles of Persian prose were replaced by Realism, Surrealism, Naturalism, etc.

\section{Inability of Persian Language and Literature Field}

After creation of academic sciences in Iran, Persian language and literature was among the first fields that quickly became academic. Now, after years we see that this field still works with the same courses and without theorizing and scientific outcomes.

In other fields, we study the works of previous years; however, in the field of humanities, especially Persian literature requires newest theories proposed in various areas to be discussed (Vafaei, 2009, p 2).

Today, there is not such an expectation about Persian language and literature and an expert of Persian language and literature is mostly expected to identify the classical Persian literature works. Furthermore, this field is not considered as artist and theorist trainer field.

One of the subjects having been discussed about among professors and educational planners for years is the correspondence of courses in this field with time, place and social needs. In recent years, efforts have occasionally been made for revision and consequently changes in the curriculum of Persian language and literature field at universities (Planning Committee of Persian language and literature, 2010, p45).

Persian language and literature field containing our identity - including old and new literature, so that Iranians' culture, civilization, history and beliefs have been replaced in it - must be studied in accordance with the existing needs and exact scientific approaches of the world. Today, new issues are proposed about literary and linguistic areas in universities around the world addressing which is necessary.

Students complained about the courses that they studied while analysis was not carried out properly. For example, proses such Beyhaqi History or Kalila and Dimna were read but not analyzed. Therefore, they were useless. Such texts required to be read analytically by students (Vafaei, Ibid, p2).

Persian literature as the most sensitive part of Iranian identity should be considered more because a part of our identity in the world is dependent to this component. The inability of educational planners in matching courses of this field with update needs has led this field to be completely separated from original literature of society and does not feed its scientific theories.

In the field of Persian language and literature, a development has been made in poetry called Contemporary Literature. This subject required to be widely proposed and more courses should be devoted to it (Ibid, p 3).

Lack of attention to analysis of literary movements makes it impossible to control the flow of Iranian literature and its imitations. "In the field of contemporary literature, lots of novels have been transformed to movies but they are not addressed at universities and the field of fiction is not considered, too. Even the information that are taught to students are not applicable, as a result; they are quickly forgotten" (Ibid, p 3).

\section{Conclusion and Solutions}

As mentioned, classical Persian literature has been one of the main poles of literature in the world. Its combination with mysticism has made Persian literature to take some aspects and be privileged in the world.

Now it has been caught in the trap of western styles and spreads intellectual bases, which are not extracted from the heart of Iranian society, or even if they are, they have taken the shape of alien formats in a way that their distinctive is difficult or even impossible.

Nowadays, theorizing about the field of Persian literature has gone beyond

Iranian universities to poetry nights, press and newspapers, it is necessary to find a solution for this special course in order to reflect its contemporary literature like previous Iranian literature which reflected the society of its time.

This field should not merely address the archives without adding any new paper to them. Undoubtedly, as long as this field is not divided to sub-branches and is taught under mere title with these courses, no success will be achieved.

Novel is a hot and controversial debate in the world of literature today that has many readers around the world. So far, Iranian novelists have not been successful in order to stare the eyes of the world like their literary predecessors.

In today's world, identifying novel and training it is more necessary than poetry arrays of an unknown poet. Therefore, courses should be injected to the body of literature or a new scientific and academic field should be created for training the art which is necessary for society.

Today, there are no more poetry nights and current poetry associations which were held at the beginning of poets' trend to modern poetry and were appropriately affective in poetry changes. 
It caused that novice poets do not enter the group of professors outside academic area, lack of presence of experienced professors was felt in youth's literary parties, and it was impossible to control the content of composed poems. Therefore, trends to these parties is one of the necessities of current Iranian literary community that they should be held quickly and transformed to a place for theorizing and creating schools for Persian literature.

On the other hand, Iran is the greatest heritor of Persian language and literature among Persian language countries and holds one of the richest poetic and prosaic literatures in the world. Although, Iran is politically under pressure from the West and autocratic societies, it can achieve many successes in different field in terms of literature. Authors of the current paper suggest that holding international seminars at different and famous universities of Iran and the world is necessary for introducing and rebuilding the face of Iran's literature. As a result, the subjects of western and eastern literature and selected works of different countries can be matched with each other in these seminars, distinction and similarities of various works and the reasons for superiority of one over the other can be expressed without prejudice and introduced to youth and teenagers. Certainly, it can be said that today's lack of such seminars on Iranian literature is felt in Iran, other Persian language countries, and all countries whether they are familiar with Iranian literature. It is hoped that by focusing on new aspects of world literature and training them to new Iranian scholars, Iranian literature again will become one of the indices of world literature as before and its influence will continue.

\section{References}

Akhgari, M.. (2000). Influence of Islamic Mysticism on Western Literature. Keyhan Farhangi 284-285 0- (June and July2000).

Salasi, M. (2011) . Iranian World Andinternationaliran. Ch.6 $6^{\text {th }}$. Tehran: Markaz Publication.

Chitik, W. (2004). An Introduction to Islamic Mysticism and Sufism.Translated by Galil Parveen. Tehran: Reaserch Institute of Imam Khomeini (RA)and the Islamic Revolution.

Durant, W. (1998) History of Civilization. Translated by Abutaleb Saremi, Abolghasem Payandeh, \& Abolghasem Tahi. Vol. $4^{\text {th }}$. Ch. $6^{\text {th }}$. Tehran: Elmi and Farhangi Press.

Shamisa, C. (1999). Style of Poetry. Ch. $4^{\text {th }}$. Tehran: Mitra Press.

Shiri, Q. (2004). Prelude on Schools of Fiction Writingin Iranian Contemporary Literature. Journal of Tabriz University Faculty of Literature and Humanities 189 year $46^{\text {th }}$. ( Winter,2004).

Shiri, Q. (2006). Postmodernism and Isfahani Fiction writing School. Elmi Pajoheshi journal of IsfahanUniversityFaculty ofLiterature and Humanities 42-43 (fall andwinter 2006).

Safa, Z. (1985). A Brief History of the Evolution of Persian Prose and Poetry. Ch. $4^{\text {th }}$.Qom:the Publish center of Islamic Bureau.

Tusi, B. (2013). Expansion of Iranian Literature and Culture in the World. Tehran: Tehran University Center of Islamic Studies-McGill University.

Karimi, M. (2002). Anton Chekhov's Influence on Contemporary Iranian Literature. Journal of Foreign Languages Research 11(Fall and Winter 2002),

LalNehru,J. (2003). Discovery of India. Translated by Mahmoud Tafazzoli. Tehran: Amir Kabir.

Vafaei, A. (1999). Studying Conference of Necessities in the Field of Persian Language and Literature. Literature Book of the Month NO.13 ${ }^{\text {th }}$,row 137,( May 1999).

Planning Committee of Persian Literature", Persian Language and Literature Committee Report, Book of the month on Literature, No. $45^{\text {th }}$,row159, January 2010. 